\title{
Lessons Learnt From The Pandemic: My Perspective
}

\author{
Pallavi Lande-Marghade
}

The countdown has begun to end of 2020. A traitor! A wasted year! Worst year! Funny memes were created around it. Nevertheless, it has indeed been a tough year for all of us.

However, in my experience, this year has been one of my best teachers so far. I sit down at my desk to reflect upon the events this year which has significantly reshaped my life.

Here I enumerate the lessons which have empowered me for a lifetime.

Acceptance- I accepted the reality without complaining, however deep down I was worried about the uncertainty of the disease, effects of the disease on myself, my family and humanity in general. However, this never came in my way of performing my duties as a doctor at the frontline.

Resilience- This year was an emergence of an endurable and resilient version of myself. The surreal circumstances I faced during the lockdown compelled me not to lose my cool and carry on, albeit with moments of frustration. I have definitely emerged out stronger.

Realisation-I wasn't alone in my journey. God has blessed me with beautiful parents, a loving husband, a doting brother and gems whom we call friends who kept checking on my physical and mental wellbeing. I am eternally grateful to one and all for the support.

Health and Wellbeing- Self-care should not be equated with self-indulgence. Rather it should be a priority as one cannot fill from an empty bucket. I decided to transform myself on the fitness front and bring out my strongest version.

Love-Family first always! Distance makes love grow fonder, I have experienced it in a real sense.

Art of Giving-The fact that everything is non-permanent in this world, and nothing belongs to you, has reinforced my faith in charity.

Opportunities- while we were crippled with restrictions, conferences looked like a distant reality. Technological advancements however created a land of opportunities. Ourventure AnaesthesiaTV got a new lease on life and since then it's no looking back.

Collaboration- PainTV was born through collaboration with the dignitaries in pain medicine and dissemination of knowledge looked unstoppable.

Preparation- The worst times we faced during this year made us prepared for the worst eventuality physically, mentally, emotionally and financially.

Hope- A breakthrough in the world of vaccine research has happened and hope thus lingers around various vaccines against the SARS- COVID 19virus.

Anecdotally I am hopeful about the new year bringing more happy reunions, peace and health to all.

Amen!

${ }^{1}$ Department of Anaesthesia, King's College Hospital London, Dubai,

UAE.

Address of Correspondence

Dr.PallaviLande-Marghade

Specialist Anaesthesiologist, King's College Hospital London, Dubai,

UAE.

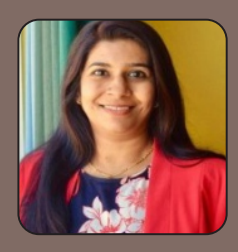

Dr Pallavi Lande-Marghade

\section{How to Cite this Article \\ Marghade-Lande P | Lessons Learnt From The Pandemic: My Perspective | Journal of Anaesthesia and Critical Care Case Reports | September-December 2020; 6(3): 01.}

DOI: 10.13107/jaccr.2021.v06i03.153

This is an Open Access article distributed under the terms of the Creative Commons Attribution Non-Commercial-Share Alike 4.0 License (http://creativecommons.org/licenses/by-nc-sa/4.0) which allows others to remix, tweak, and build upon the work non-commercially as long as appropriate credit is given and the new creation are licensed under the identical terms.

01 | Journal of Anaesthesia and Critical Care Case Reports | Volume 6 | Issue 3 | September-December 2020 | Page 01 